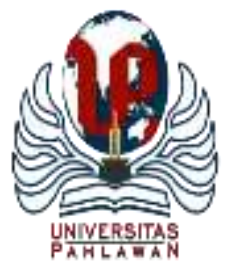

Edukatif : Jurnal Ilmu Pendidikan Volume 3 Nomor 6 Tahun 2021 Halm 3962 - 3974

EDUKATIF: JURNAL ILMU PENDIDIKAN

Research \& Learning in Education

https://edukatif.org/index.php/edukatif/index

\title{
Pengaruh Locus Of Control dan Kompetensi Diri terhadap Kesiapan Kerja Mahasiswa IAIN Lhokseumawe
}

\author{
Setiawan $^{1 凶}$, Yusnaini ${ }^{2}$ \\ Institut Agama Islam Negeri Lhokseumawe ${ }^{1,2}$ \\ E-mail : setiawan8872@ gmail.com ${ }^{1}$, yusnaini.ilyas@ gmail.com² ${ }^{2}$
}

\begin{abstract}
Abstrak
Kesiapan kerja mahasiswa sangat tergantung pada kompetensi diri dan locus of control yang dimilikinya. Kompetensi diri dan locus of control dapat dikembangkan atau dilatih dengan cara menjadikan mahasiswa lebih aktif dalam kegiatan kampus baik akademik maupun kegiatan organisasi. Penelitian ini bertujuan (1) untuk mengetahui seberapa besar pengaruh kompetensi diri terhadap kesiapan kerja mahasiswa IAIN Lhokseumawe, 2) untuk mengetahui seberapa besar pengaruh locus of control terhadap kesiapan kerja mahasiswa IAIN Lhokseumawe. Penelitian ini menggunakan metode kuantitatif dengan melibatkan 257 responden mahasiswa dan 109 responden alumni sebagai sampel penelitian. Hasil penelitian menunjukkan bahwa: tidak terdapat pengaruh yang positif dan signifikan kompetensi diri, locus of control terhadap kesiapan kerja mahasiswa IAIN Lhokseumawe. Mahasiswa yang orientasi loc internal lebih siap kerja dibandingkan dengan mahasiswa yang orientasi loc eksternal. Peran lembaga IAIN terhadap kompetensi diri mahasiswa dalam menghadapi kesiapan kerja belum maksimal dan Lembaga IAIN Lhokseumawe perlu berbenah diri agar lulusannya nanti siap bekerja yang salah satunya merevisi mata kuliah sesuai dengan perubahan zaman, membentuk wadah untuk pengembangan bakat dan minat mahasiswa dan menjadikan kewirausahaan sebagai mata kuliah lintas fakultas.
\end{abstract}

Kata Kunci: Kompetensi diri, Locus of control, Kesiapan Kerja, mahasiswa

\begin{abstract}
Students' work readiness is highly dependent on their self-competence and locus of control. Self-competence and locus of control can be developed or trained by making students more active in campus activities, both academic and organizational activities. This study aims to determine how much influence self-competence and locus of control have on the job-readiness of IAIN Lhokseumawe students. 2) To find out how much influence the Internal locus of control has on the work readiness of IAIN Lhokseumawe students. This study uses quantitative methods involving 257 student respondents and 109 alumni respondents as research samples. The results showed that: There was no positive and significant effect of self-competence, locus of control on work readiness of IAIN Lhokseumawe students. Students with internal orientation are more work-ready than students with external orientation. The role of the IAIN institution on students' self-competence in dealing with work readiness has not been maximized and the IAIN Lhokseumawe Institution needs to improve itself so that its graduates will be ready to work, one of which is revising courses according to changing times, forming a forum for developing student talents and interests and making entrepreneurship a crossfaculty course.
\end{abstract}

Keywords: self-competence, locus of control, job readiness, students

Copyright (c) 2021 Setiawan, Yusnaini

$\triangle$ Corresponding author

Email : setiawan8872@gmail.com

DOI : https://doi.org/10.31004/edukatif.v3i6.1357

ISSN 2656-8063 (Media Cetak)

ISSN 2656-8071 (Media Online)

Edukatif : Jurnal Ilmu Pendidikan Vol 3 No 6 Tahun 2021 p-ISSN 2656-8063 e-ISSN 2656-8071 


\section{Pengaruh Locus Of Control dan Kompetensi Diri terhadap Kesiapan Kerja Mahasiswa IAIN Lhokseumawe - Setiawan, Yusnaini \\ DOI: https://doi.org/10.31004/edukatif.v3i6.1357}

\section{PENDAHULUAN}

Mahasiswa merupakan individu yang memiliki potensial dalam memahami perubahan dan perkembangan di dunia pendidikan dan lingkungan masyarakat. Mahasiswa juga merupakan calon intelektual yang sedang belajar secara formal di perguruan tinggi. Menurut Siswoyo mahasiswa adalah "individu yang sedang menuntut ilmu ditingkat perguruan tinggi, baik negeri maupun swasta atau lembaga lain yang setingkat dengan perguruan tinggi"'(Siswoyo, 2007). Perguruan tinggi akan mengubah cara berpikir mahasiswa menjadi lebih matang ke arah yang lebih logis, kritis dan inovatif. Mahasiswa di perguruan tinggi tidak hanya ilmu saja yang diperoleh, tetapi mahasiswa juga dilatih untuk dapat mengembangkan kemandirian, bakat atau kompetensi diri yang melekat pada mereka. Memiliki peran dan tanggung jawab dalam kemajuan bangsa, yang nantinya akan menjadi orang-orang yang ahli dan profesional dalam bidang pemerintahan maupun dalam bidang yang lain. Selain dari itu mahasiswa juga sebagai agen perubahan yang mengajak seluruh masyarakat untuk berobah menuju yang lebih baik melalui berbagai ilmu, gagasan, serta pengetahuan yang mereka miliki.

Kemampuan mahasiswa secara akademik merupakan bagian dari kompetensi diri yakni kemampuan kognitif atau pengetahuan. Sedangkan kompetensi diri meliputi beberapa dimensi lainnya yaitu adanya keterampilan atau bakat yang ada pada diri, ketertarikan atau adanya minat yang tinggi terhadap suatu bidang, terjadi perubahan sikap dan nilai yang melekat pada mahasiswa juga merupakan sebagai standar prilaku atau sikap. Kompetensi itu sendiri adalah suatu kemampuan untuk melaksanakan suatu pekerjaan atau tugas yang dilandasi atas keterampilan dan pengetahuan serta didukung oleh sikap kerja yang dituntut oleh pekerjaan tersebut (Wibowo, 2010). Dengan demikian kompetensi diri yang dilandasi kemampuan bidang akademik keterampilan serta sikap yang melekat pada diri dan berlangsung lama serta dapat memprediksi perilaku dalam melaksanakan setiap pekerjaan.

Kemampuan akademik dan keterampilan yang melekat pada mahasiswa sangat dipengaruhi oleh locus of control individu mahasiswa itu sendiri terutama locus of control internal. Locus of control merupakan salah satu aspek kepribadian yang dimiliki oleh setiap individu, yang pada dasarnya menunjukkan pada keyakinan individu mengenai sumber penyebab dari peristiwa-peristiwa yang terjadi pada dirinya baik itu suatu keberhasilan atau kegagalan yang dialaminya. Menurut Rotter locus of control adalah merupakan derajat keyakinan individu bahwa mereka mampu mengontrol event-event dalam kehidupannya (locus of control internal) atau keyakinan individu bahwa lingkunganlah yang mampu mengontrol event-event dalam kehidupannya (locus of control external) (B. Rotter, 1996).

Seiring terjadinya perubahan pada masa remaja menuju masa dewasa mahasiswa dituntut sudah harus mempunyai kemampuan untuk berpikir secara dewasa, mampu mengontrol diri sendiri termasuk mengontrol locus of control. Artinya mahasiswa harus menyadari bahwa kualitas kompetensi diri sangat ditentukan oleh usaha yang keras dan punya inisiatif yang tinggi dalam belajar. Keyakinan dalam mengendalikan diri akan ditunjukkan dengan adanya usaha yang tinggi jika ingin berhasil (Mardiani, Zulaihati, \& Sumiati, 2021).

Pengaruh pengontrolan locus of control ini secara baik akan memberikan keyakinan pada kemampuan diri mahasiswa sendiri dan ini dapat membuat semakin besarnya kesiapan kerja yang dimiliki oleh mahasiswa.

Permasalahan yang dihadapi sekarang ini berdasarkan studi pendahuluan masih banyak mahasiswa IAIN Lhokseumawe yang bekerja tidak sesuai pada bidang pekerjaan berdasarkan minat dan kompetensi yang dimilikinya. Hal ini juga di dukung oleh informasi dari Kementerian Riset, Teknologi, dan Pendidikan Tinggi mencatat sekitar $8,8 \%$ dari total 7 juta atau berkisar 630.000 pengangguran di Indonesia adalah sarjana. Kondisi tersebut sangat mengkhawatirkan mengingat persaingan untuk mendapatkan pekerjaan akan semakin ketat dengan datangnya Revolusi Industri 4.0. Menurut Menteri Muhammad Nasir,perguruan tinggi berperan strategis dalam mempersiapkan tenaga kerja yang terampil dan berpendidikan tinggi serta berwawasan global. Perguruan tinggi harus mampu menghasilkan sumber daya yang mampu bersaing secara global (Seftiawan, 2018). 
Sejalan dengan hal tersebut, Institut Agama Islam Negeri Lhokseumawe telah melakukan pelacakan terhadap keberadaan alumni 5 tahun terakhir dari tahun 2012-2017. Berdasarkan informasi dari Tim Borang IAIN Lhokseumawe diperoleh informasi bahwa jumlah lulusan dari tahun 2012-2017 sebanyak 3.951 mahasiswa dan dari jumlah tersebut yang memberi respon terhadap keberadaan alumni sebanyak 823 atau berkisar 21\%. Ini berarti $79 \%$ mahasiswa tidak terlacak, hal ini dimungkinkan data mahasiswa sudah berpindah alamat atau nomor ponsel mahasiswa sudah berubah. Berdasarkan data pelacakan ini, dari 823 mahasiswa hanya 195 orang atau berkisar 24\% mahasiswa yang sudah bekerja sesuai dengan bidang keahlian program studinya, berarti sekitar $76 \%$ merupakan mahasiswa yang bekerja tidak sesuai dengan bidang keahliannya dan menganggur.

Berdasarkan permasalahan di atas, dapat diidentifikasikan bahwa kesiapan kerja mahasiswa masih rendah. Kesiapan kerja mahasiswa merupakan suatu kemampuan yang dimiliki oleh mahasiswa baik di bidang akademik secara kognitif, adanya ketrampilan, perubahan sosial dan emosional secara matang untuk memasuki dunia kerja yang sesuai dengan kemampuan diri. Pool dan Sewell menyatakan bahwa kesiapan kerja adalah "memiliki keahlian, ilmu pengetahuan, pemahaman dan kepribadian yang membuat seseorang bisa memilih dan merasa nyaman dengan pekerjaanya sehingga menjadi puas dan akhirnya meraih sukses"(Pool \& Sewell, 2007). Berdasarkan pernyataan ini dapat dikatakan bahwa kesiapan kerja sangat tergantung pada kualitas kompetensi diri yang dimiliki oleh mahasiswa dalam memasuki dunia kerja nantinya. Kesiapan kerja juga sangat didukung oleh keyakinan diri dalam berusaha untuk melatih dan mengembangkan kompetensi diri selama perkuliahan. Tidak hanya diri mahasiswa itu sendiri, pihak lembaga khususnya IAIN Lhokseumawe juga perlu merefleksikan diri dalam memperbaiki diri baik dari segi kurikulum yang sesuai dengan masanya. Adapun Tujuan dari penelitian ini adalah (1) untuk mengetahui besarnya pengaruh kompetensi diri terhadap kesiapan kerja mahasiswa IAIN Lhokseumawe, (2) untuk mengetahui besarnya pengaruh locus of control terhadap kesiapan kerja mahasiswa IAIN Lhokseumawe, (3) untuk mengetahui peran IAIN Lhokseumawe dalam mempersiapkan mahasiswa untuk siap kerja setelah menjadi sarjana, dan (4) untuk mengetahui hal-hal yang harus dilakukan lembaga IAIN Lhokseumawe dalam mempersiapkan mahasiswa agar mempunyai kesiapan kerja setelah menjadi sarjana.

\section{METODE PENELITIAN}

Pendekatan penelitian yang digunakan dalam penelitian ini adalah mix method dengan jenis penelitian ex post facto,Sugiyono yang mengemukakan bahwa penelitian Ex Post Facto adalah suatu penelitian yang dilakukan untuk meneliti peristiwa yang telah terjadi dan kemudian mengenalisis ke belakang untuk mengetahui faktor-faktor yang dapat menyebabkan timbulnya kejadian tersebut. Dalam penelitian tidak ada manipulasi langsung terhadap variabel independent (Sugiono, 2013). Sukardi juga menjelaskan bahwa penelitian ex post facto merupakan penelitian dimana variabel-variabel bebas telah terjadi ketika penelitian mulai dengan pengamatan variabel terikat dalam suatu penelitian (sukardi, 2012). Lokasi penelitian di kampus Institut Agama Islam Negeri Lhokseumawe dengan populasi mahasiswa semester 7 yang ada di seluruh fakultas IAIN Lhokseumawe. Pengambilan sampel menggunakan simple random sampling dalam menentukan ukuran sampel peneliti menggunakan rumus yang dikemukakan oleh Slovin dalam Umar menyatakan bahwa untuk menentukan minimal sampel yang dibutuhkan jika populasi diketahui dapat digunakan rumus sebagai berikut:

$$
n=\frac{N}{1+N e^{2}}
$$

Dimana:

$\mathrm{N}$ = Jumlah seluruh mahasiswa akhir IAIN Lhokseumawe 
$\mathrm{n}=$ Jumlah mahasiswayangdijadikan sampel

e =Tingkat kesalahanyangdiperkenankan(Husein, 2004).

Mengenai Pengumpulan data di analisis sesuai dengan prosedur dari teori Miles \& Huberman dari pendekatan kualitatif selanjutnya di padukan dengan kuantitatif dengan statistik inferensi dengan korelasi antar variabel dan pengaruh tiap variabel dengan menggunakan regresi linear berganda dari datang ke untuk variabel locus of control, kompetensi diri dan kesiapan kerjadengan tujuan untuk memperoleh informasi dari para responden terhadap locus of control. Untuk itu diperlukan langkah-langkah dalam melakukan pengujian hipotesis pada regresi linear sederhana yaitu adanya pengujian asumsi klasik dapat dikatakan sebagai uji prasyarat analisis untuk menganalisa regresi linear sederhana (hanya menggunakan 2 variabel penelitian).

Uji Asumsi Klasik bertujuan untuk memastikan bahwa hasil penelitian adalah valid dengan data yang digunakan secara teori adalah tidak bias, konsisten dan penaksiran koefisienan regresinya efisien (Gujarati, 2003). Dalam penelitian ini uji asumsi klasik yang dilakukan adalah pengujian normalitas dan linieritas.

Selanjutnya pengujian hipotesis dalam penelitian ini menggunakan regresi linear sederhana, yaitu untuk mengetahui pengaruh dari variabel bebas (kompetensi diri) terhadap variabel terikat (kesiapan kerja). Adapun rumus yang digunakan untuk regresi linear sederhana dengan variabel bebas yaitu kompetensi diri (X), sedangkan variabel terikat yaitu kesiapan kerja (Y):

Persamaan regresi ini dapat atau tidak memprediksikan atau meramalkan variabel dependen dengan baik. Ini berarti melihat pengaruh variabel bebas secara bersamaan atau parsial berpengaruh secara signifikan. Untuk itu perlu adanya uji keberartian dari model atau persamaan regresi yaitu Uji keberartian Koefisien regresi (uji t).

Uji t digunakan untuk mengetahui secara variabel bebas (kompetensi diri) secara terpisah (parsial) berpengaruh secara signifikan terhadap variabel terikat (kesiapan kerja). Perhitungan uji t ini menggunakan aplikasi SPSS dengan kriteria sebagai berikut:

a. Apabila jika - $t$ hitung < $-\mathrm{t}$ tabel atau $\mathrm{t}$ hitung $>\mathrm{t}$ tabel, maka regresi berarti atau dapat dikatakan ada pengaruh yang signifikan antar variabel bebas dan variabel terikat secara parsial.

b. Apabila nilai signifikansi $<0,05$, maka regresi berarti atau dapat dikatakan ada pengaruh yang signifikan antar variabel bebas dan variabel terikat secara parsial.

\section{HASIL DAN PEMBAHASAN PENELITIAN}

Bagian ini akan membahas mengenai hasil serta pembahasan terdapat mahasiswa semester 7 tahun ajaran 2019/2020 berjumlah sebanyak 257 responden. Pada Penelitian ini setiap responden mengisi 3 jenis angket yaitu angket locus of control, angket kompetensi diri dan angket kesiapan kerja. Selain dari itu setiap responden juga diberikan wawancara secara tertulis untuk mendukung informasi penelitian.

\section{Paparan Data}

\section{Locus of Control (Loc)}

Locus of control merupakan aspek kepribadian individu mengenai keyakinan kesuksesan atau keberhasilan yang dipengaruhi oleh diri sendiri (loc internal) atau dari luar dirinya (loc eksternal). Adapun hasil angket yang diperoleh jumlah responden yang mempunyai orientasi loc internal sebanyak 165 responden atau sebesar $64,20 \%$. Sedangkan orientasi loc eksternal sebanyak 92 responden atau sebesar 35,80\%. Persentase loc internal kurang menggembirakan, seharusnya responden yang merupakan mahasiswa semester 7 seiring dengan bertambahnya umur dan cara berpikir yang lebih maju sudah mempunyai rasa tanggung jawab akan kesuksesan secara internal. 


\section{Kompetensi diri}

Berdasarkan rekapitulasi angket bahwa indikator konsep diri mempunyai persentase terbesar yaitu sebesar 87,39\% mencapai kategori tingkat persentase sangat baik, selanjutnya indikator terbesar kedua adalah motif sebesar $83,30 \%$ mencapai kategori tingkat persentase sangat baik, indikator terbesar ketiga adalah keterampilan sebesar $80,42 \%$ mencapai kategori tingkat persentase baik, indikator terbesar keempat yaitu pengetahuan sebesar 79,28\% mencapai kategori persentase baik dan indikator sifat mempunyai persentase terendah sebesar 78,50\% mencapai kategori persentase baik. Secara keseluruhan kompetensi diri mempunyai persentase sebesar $82,47 \%$ dan termasuk kategori sangat baik. Ini dapat disimpulkan mahasiswa IAIN Lhokseumawe mempunyai kompetensi diri yang sangat baik.

\section{Kesiapan Kerja}

Berdasarkan angket kesiapan kerja bahwa indikator responsibility, flexibility dan komunikasi berada di atas $81 \%$, ini menunjukkan bahwa ketiga indikator tersebut termasuk kategori sangat baik. Untuk indikator self-view dan healthy and safety nilai persentase berada pada kategori baik. Ini dapat dikatakan secara keseluruhan kesiapan kerja mempunyai persentase $81,32 \%$ dan berkategori sangat baik.

\section{Pengujian Hipotesis \\ Pengujian hipotesis pertama}

Ho :Tidak terdapat pengaruh yang positif dan signifikan Kompetensi diri terhadap kesiapan kerja mahasiswa IAIN Lhokseumawe.

$\mathrm{Ha}$ :Terdapat pengaruh yang positif dan signifikan Kompetensi diri terhadap kesiapan kerja mahasiswa IAIN Lhokseumawe.

Berdasarkan hasil perhitungan diperoleh nilai t hitung untuk kompetensi diri sebesar -0,563 atau nilai sig. Sebesar 0,574. Nilai signifikan ini lebih besar dari 0,05 $(0,574>0,05)$, berdasarkan kriteria hipotesis menunjukkan bahwa terima Ho. Ini berarti tidak terdapat pengaruh yang positif dan signifikan kompetensi diri terhadap kesiapan kerja mahasiswa IAIN Lhokseumawe, sehingga variabel ini (kompetensi diri) tidak dapat dijadikan sebagai prediktor untuk menilai variabel kesiapan kerja.

\section{Pengajuan hipotesis kedua}

Ho : Tidak terdapat pengaruh yang positif dan signifikan kompetensi diri mahasiswa yang berorientasi loc internal terhadap kesiapan kerja.

$\mathrm{Ha}$ : Terdapat pengaruh yang positif dan signifikan kompetensi diri mahasiswa yang berorientasi loc internal terhadap kesiapan kerja.

Berdasarkan hasil perhitungan diperoleh nilai t hitung untuk kompetensi diri loc internal sebesar 0,991 atau nilai sig. Sebesar 0,323. Nilai signifikan ini lebih besar dari $0,05(0,323>0,05)$, berdasarkan kriteria hipotesis menunjukkan bahwa terima Ho. Ini berarti tidak terdapat terdapat pengaruh yang positif dan signifikan kompetensi diri mahasiswa yang berorientasi loc internal terhadap kesiapan kerja, sehingga variabel ini (kompetensi diri loc internal) tidak dapat dijadikan sebagai prediktor untuk menilai variabel kesiapan kerja.

\section{Pengajuan hipotesis ketiga}

Ho : Tidak terdapat pengaruh yang positif dan signifikan kompetensi diri mahasiswa yang berorientasi $l o c$ eksternal terhadap kesiapan kerja.

Ha : Terdapat pengaruh yang positif dan signifikan kompetensi diri mahasiswa yang berorientasi loc eksternal terhadap kesiapan kerja.

Berdasarkan hasil perhitungan diperoleh nilai t hitung untuk kompetensi diri loc eksternal sebesar -0,77 atau nilai sig. Sebesar 0,443. Nilai signifikan ini lebih besar dari $0,05(0,443>0,05)$, berdasarkan kriteria 
hipotesis menunjukkan bahwa terima Ho. Ini berarti tidak terdapat terdapat pengaruh yang positif dan signifikan kompetensi diri mahasiswa yang berorientasi loc eksternal terhadap kesiapan kerja, sehingga variabel ini (kompetensi diri loc eksternal) tidak dapat dijadikan sebagai prediktor untuk menilai variabel kesiapan kerja.

\section{Pengajuan hipotesis keempat}

Ho : Mahasiswa yang orientasi loc internal lebih tidak siap kerja dibandingkan dengan mahasiswa yang orientasi loc eksternal.

Ha : Mahasiswa yang orientasi loc internal lebih siap kerja dibandingkan dengan mahasiswa yang orientasi loc eksternal.

Karena data tidak berdistribusi normal, maka perhitungan hipotesis menggunakan statistik non parametric, tepatnya perhitungan Man-Whiteney. Hasil perhitungan diperoleh nilai signifikan sebesar 0,000, nilai ini lebih kecil dari $0,05(0,00<0,05)$ ini menunjukkan bahwa Ho ditolak dan Ha diterima. Sehingga mahasiswa yang orientasi loc internal lebih siap kerja dibandingkan dengan mahasiswa yang orientasi $l o c$ eksternal.

\section{Hasil Wawancara}

Wawancara dilakukan pada 2 jenis responden, responden yang sedang aktif di akhir semester dan mahasiswa yang telah menjadi alumni.

\section{Hasil Wawancara dengan Mahasiswa Aktif}

Wawancara dilakukan pada 170 responden mahasiswa dengan empat topik pembicaraan, yaitu:

1) Keyakinan diri untuk mudah mendapatkan pekerjaan.

2) Persiapan yang dilakukan mahasiswa dalam rangka mendapatkan pekerjaan.

3) Dukungan lembaga IAIN Lhokseumawe terhadap mahasiswa dalam rangka mendapatkan pekerjaan.

4) Peranan lembaga IAIN Lhokseumawe agar mahasiswa mempunyai kesiapan kerja setelah menjadi sarjana.

Berdasarkan hasil wawancara diperoleh bahwa 51\% mahasiswa yakin dan $49 \%$ tidak yakin akan mendapatkan pekerjaan baik yang sesuai dengan program studi maupun di luar bidang studi. Kebanyakan alasan mahasiswa yang yakin akan mendapatkan pekerjaan yaitu mereka meyakini dengan mendalami atau mempelajari ilmu bidang studi akan mudah mendapatkan pekerjaan tanpa melihat kemampuan yang lain. Sedangkan mahasiswa yang tidak yakin mendapatkan pekerjaan mempunyai alasan bahwa untuk mendapatkan pekerjaan tidak hanya cukup menguasai ilmu bidang studi, tetapi harus mempunyai keahlian yang lain, mengingat banyak pencari kerja dengan kemampuan yang lebih mapan dan saling berkompetisi.

Untuk topik wawancara kedua mahasiswa atau responden sadar akan apa yang harus dipersiapkan agar mudah mendapatkan pekerjaan. Seperti mendalami ilmu secara akademik, kemudian mengasah keahlian yang telah dimiliki, mengikuti pelatihan-pelatihan yang mendukung pekerjaan dan lain sebagainya. Namun hasil jawaban mereka ini hanya sekedar keinginan dan belum sepenuhnya dilaksanakan.

Selanjutnya topik wawancara ketiga peran atau dukungan yang telah diberikan oleh IAIN Lhokseumawe, mahasiswa merasa peran lembaga untuk kemajuan akademik yang terkait dengan bidang program studi sudah memadai. Tetapi mahasiswa belum mengaitkan peran lembaga di luar bidang studi yang dapat mengasah kemampuan mereka.

Topik wawancara terakhir adalah yang harus dilakukan oleh lembaga IAIN Lhokseumawe agar mahasiswa mempunyai kesiapan kerja setelah menjadi sarjana. Hasil wawancara menunjukkan hampir semua responden menginginkan lembaga IAIN Lhokseumawe untuk lebih banyak memberikan keterampilan, pelatihan-pelatihan yang tidak hanya dibidang keilmuan tetapi juga diluar bidang studi dan pengamalaman yang cukup agar mahasiswa siap kerja setelah menjadi sarjana. 


\section{Wawancara dengan Alumni}

Wawancara dilakukan pada 100 responden yang berasal dari alumni IAIN Lhokseumawe dengan empat topik wawancara yaitu:

1. Keyakinan selama masa perkuliahan dulu terhadap kesiapan kerja setelah menjadi sarjana.

2. Peran perguruan tinggi (IAIN Lhokseumawe) agar mahasiswa siap menghadapi dunia kerja setelah menjadi sarjana?

3. Persiapan yang dilakukan mahasiswa IAIN Lhokseumawe sekarang ini agar mereka mempunyai kesiapan kerja setelah menjadi sarjana.

4. Peran lembaga (IAIN Lhokseumawe) agar mahasiswa mempunyai kesiapan kerja setelah menjadi sarjana.

Berdasarkan hasil wawancara diperoleh sebanyak 31,25\% alumni meyakini akan mendapatkan pekerjaan pada saat masih kuliah dan $68,75 \%$ alumni tidak meyakini mendapatkan pekerjaan setelah menjadi sarjana. Kebanyakan alasan mereka bahwa untuk mendapatkan pekerjaan tidak cukup hanya mendalami ilmu pengetahuan sesuai dengan bidang studi, namun banyak sekali keahlian yang harus dimiliki oleh mahasiswa terutama dibidang informatika atau setidaknya mahasiswa juga harus menguasai komputer. Hal ini juga dikarenakan untuk mendapatkan pekerjaan seseorang harus mampu berkompetisi dengan yang lainnya, yang tentu ilmu secara teori dan keahlian yang menentukan akan kemenangan untuk mendapatkan pekerjaan.

Untuk topik wawancara kedua, secara umum peran IAIN Lhokseumawe terhadap kesiapan kerja mahasiswa masih belum maksimal atau dapat dikatakan peran yang diberikan masih sedikit kepada mahasiswa untuk kesiapan kerja. Untuk meningkatkan keahlian (skill) di IAIN Lhokseumawe masih sangat minim, kemudian praktek dan teori yang secara kurikulum tidak seimbang.

Pada topik wawancara ketiga, persiapan yang harus dilakukan oleh mahasiswa sekarang ini berdasarkan pengalaman alumni dalam mencari kerja yaitu mahasiswa harus mempunyai kompetensi diri yang kuat, harus punya keahlian, tidak hanya terpaku pada teori belajar program studi. Selain itu mahasiswa juga harus mempunyai mental yang kuat dengan cara mengikuti komunitas atau organisasi.

Topik wawancara keempat, yang harus dilakukan oleh lembaga IAIN Lhokseumawe agar mahasiswa mempunyai kesiapan kerja setelah menjadi sarjana yaitu: pengembangan ilmu pengetahuan sesuai dengan program studi harus disesuaikan dengan kebutuhan zaman, kemudian agar lembaga lebih banyak mengetahui tentang kompetensi diri yang dibutuhkan oleh dunia kerja, maka lembaga harus dapat melakukan pertemuanpertemuan dengan para alumni dan ini dapat dijadikan sebagai pertemuan berkala. Melakukan kegiatankegiatan seminar atau pelatihan-pelatihan baik yang menyangkut ilmu bidang studi maupun diluar bidang studi.

\section{Hasil Forum Group Discussion (FGD)}

Materi dalam FGD yaitu kesiapan kerja mahasiswa, peran perguruan tinggi terhadap kesiapan kerja mahasiswa, kompetensi lulusan mahasiswa dan kurikulum/pembelajaran yang mendukung kompetensi diri mahasiswa. Hasil diskusi dalam FGD ini secara umum yaitu:

1. Perlu adanya pelatihan-pelatihan atau seminar tentang kewirausahaan, atau bahkan kewirausahaan dijadikan sebagai matakuliah umum atau matakuliah lintas fakultas.

2. Perlu adanya suatu organisasi yang dapat menjembatani antara mahasiswa dan alumni, sehingga mahasiswa yang baru lulus dapat dengan mudah mendapatkan informasi lapangan kerja.

3. Perlu dibentuk suatu wadah yang dapat mengembangkan bakat dan minat mahasiswa.

4. Perlu adanya revisi-revisi matakuliah sesuai dengan kemajuan zaman

5. Mahasiswa diarahkan lebih banyak menggunakan IT (informatika dan teknologi).

6. Menyediakan prasarana-prasarana yang mendukung keilmuan dan kompetensi diri mahasiswa. 


\section{A. PEMBAHASAN}

1. Pengaruh kompetensi diri terhadap kesiapan kerja mahasiswa IAIN Lhokseumawe

Hasil pengujian hipotesis menunjukkan bahwa tidak ada pengaruh yang positif dan signifikan kompetensi diri terhadap kesiapan kerja mahasiswa IAIN Lhokseumawe. Hasil perhitungan data menunjukkan bahwa rata-rata persentase kompetensi diri sebesar $82,47 \%$ dan merupakan kategori yang sangat baik. Secara teori seharusnya seseorang yang mempunyai kompetensi diri yang baik akan lebih siap bekerja. Mahasiswa IAIN Lhokseumawe sangat cenderung menilai kompetensi diri pada ilmu pengetahuan yang diperoleh pada program studi, mereka beranggapan bahwa semakin besar nilai indeks prestasi semakin besar pula kesempatan untuk mendapatkan pekerjaan. Mereka tidak menyadari bahwa kompetensi diri itu tidak hanya bidang keilmuan program studi, ilmu yang lain juga harus sedikit banyaknya dikuasai. Tetapi harus mempunyai keahlian (skill) yang justru banyak dibutuhkan oleh kelompok pengguna pekerja atau keahlian yang dibutuhkan untuk diri sendiri yang nantinya akan dimanfaatkan pada usaha sendiri.

Hasil perhitungan menunjukkan bahwa besarnya pengaruh kompetensi diri terhadap kesiapan kerja mahasiswa IAIN Lhokseumawe sebesar $0,1 \%$, ini termasuk nilai yang berkategori rendah. Ini menunjukkan bahwa wawasan kepribadian mahasiswa masih kurang, mereka meyakini bahwa dengan belajar dan mengembangkan ilmu pengetahuan saja sudah merupakan kompetensi yang bagus, tetapi disaat berbicara tentang kesiapan kerja dan dunia kerja pada jaman sekarang ini, mereka merasa belum begitu siap. Artinya nilai kompetensi diri mereka tidak sesuai dengan nilai kesiapan kerja yaitu nilai kompetensi diri yang tinggi tidak diikuti dengan nilai kesiapan kerja yang tinggi pula atau sebaliknya.

2. Pengaruh kompetensi diri mahasiswa yang orientasi locus of control Internal terhadap kesiapan kerja mahasiswa IAIN Lhokseumawe

Berdasarkan hasil pengujian hipotesis menunjukkan bahwa tidak terdapat terdapat pengaruh yang positif dan signifikan kompetensi diri mahasiswa yang berorientasi loc internal terhadap kesiapan kerja. Seharusnya orang yang mempunyai orientasi loc internal lebih bertanggung jawab atas kesuksesan itu pada diri sendiri, orang tersebut lebih giat dan bekerja keras untuk memperoleh kesuksesan, sehingga kompetensi diri mereka akan lebih terasah dan mereka lebih siap bekerja. Namun demikian hasil yang diperoleh besarnya pengaruh kompetensi diri mahasiswa yang berorientasi loc internal sebesar $0,6 \%$ dan berkategori sangat rendah. Ini disebabkan nilai-nilai kompetensi diri pada mahasiswa tidak tergali dengan maksimal, salah satu penyebabnya belum tersedianya prasarana yang mendukung mahasiswa untuk melakukan pengembangan diri.

Kemudian lembaga belum pernah mendeteksi awal mahasiswa akan bakat dan minat, padahal dengan mendekteksi awal bakat dan minat mahasiswa akan menjadi aset yang sangat baik bagi lembaga, lembaga dapat membentuk prasarana yang sesuai dengan keinginan mahasiswa itu sendiri, sehingga mahasiswa mampu mengembangkan kompetensi yang ada pada diri mereka. Selain dari itu lembaga masih belum maksimal memberdayakan mahasiswa melalui pelatihan-pelatihan atau workshop tentang bagaimana menciptakan lapangan kerja sendiri, karena pangsa pasar kerja khususnya Lhokseumawe sangat minim. Pemberdayaan mahasiswa oleh lembaga dalam mengembangkan kompetensi diri dengan sendirinya dapat melatih locus of control yang mengarah ke orientasi internal, yang memang sangat diperlukan oleh setiap mahasiswa dalam kesiapan kerja.

3. Pengaruh kompetensi diri mahasiswa yang orientasi locus of control eksternal terhadap kesiapan kerja mahasiswa IAIN Lhokseumawe

Hasil pengujian hipotesis menunjukkan bahwa tidak terdapat terdapat pengaruh yang positif dan signifikan kompetensi diri mahasiswa yang berorientasi loc eksternal terhadap kesiapan kerja. Besarnya nilai pengaruh kompetensi diri mahasiswa yang berorientasi loc eksternal terhadap kesiapan kerja cenderung rendah yaitu sebesar $2,2 \%$. Ini berarti bahwa kompetensi diri mahasiswa yang loc eksternal tidak berarti terhadap kesiapan kerja mereka. 
Kompetensi diri mahasiswa yang orientasi loc eksternal tidak berkembang, hal ini dikarenakan mereka masih beranggapan keberuntungan atau kesuksesan lebih banyak bergantung diluar faktor diri sendiri. Untuk mengasah kompetensi diri mahasiswa terlebih dahulu orientasi locus of control eksternal dikembangkan atau dilatih agar mahasiswa mengarah ke loc internal. Dengan loc internal mahasiswa sudah mempunyai jiwa yang kuat untuk bertanggung jawab pada diri sendiri dalam meraih kesuksesan.

4. Perbandingan mahasiswa yang orientasi locus of control internal dan mahasiswa yang orientasi locus of control eksternal.

Hasil uji hipotesis menunjukkan bahwa mahasiswa yang orientasi loc internal lebih siap kerja dibandingkan dengan mahasiswa yang orientasi loc eksternal. Hal ini jelas bahwa mahasiswa yang orientasi loc internal lebih mampu mengembangkan diri dengan seluruh kemampuannya untuk menyelesaikan suatu permasalahan atau mendapatkan suatu keberhasilan. Sedangkan mahasiswa yang orientasi loc eksternal mempunyai sifat yang berkebalikan dari loc internal. Loc eksternal lebih bersifat pasif atau mereka lebih memasrahkan diri pada keadaan dari luar diri mereka. Sehingga mahasiswa yang orientasi loc eksternal sulit untuk mengembangkan diri.

Hasil uji hipotesis ini mendukung hasil pengujian yang dilakukan (Rahmanto, 2010) yang menunjukkan bahwa hubungan antara locus of control internal dengan kematangan karir siswa berkorelasi positif, hal ini berarti semakin tinggi semakin tinggi locus of control internal yang dimiliki siswa, maka kematangan karir siswa cenderung meningkat.

5. Peran lembaga IAIN Lhokseumawe dalam mempersiapkan mahasiswa untuk siap bekerja setelah menjadi sarjana

Berdasarkan hasil wawancara mahasiswa dan alumni menunjukkan bahwa IAIN Lhokseumawe belum memberikan peran yang maksimal. Peran yang mendukung hanya bidang pengajaran program studi, tetapi pratek yang berhubungan dengan bidang ilmu program studi masih sangat tidak seimbang. Selain dari itu prasarana yang tersedia belum mendukung mahasiswa untuk siap kerja setelah menjadi sarjana. Bengkel untuk pengembangan bakat dan minat mahasiswa belum ada di lembaga. Organisasi-organisasi yang terbentuk di lembaga IAIN Lhokseumawe masih merupakan organisasi standar sebuah perguruan tinggi, belum adanya organisasi yang mendukung pengembangan kompetensi diri mahasiswa.

Rendahnya peran lembaga IAIN terhadap kompetensi diri mahasiswa dalam menghadapi kesiapan kerja juga terlihat dari keyakinan mahasiswa untuk mudah mendapatkan pekerjaan baik yang sesuai dengan program studi atau bekerja di luar bidang studi (baik itu bisnis individual atau yang lainnya) yaitu 51\% mahasiswa yang aktif yakin akan mudah mendapatkan pekerjaan, tetapi hanya 31,25\% alumni yakin untuk mendapatkan pekerjaan setelah sarjana. Mahasiswa yang sedang aktif hanya mengetahui pendalaman ilmu saja yang sesuai dengan program studi, tetapi mereka belum merasakan bagaimana sulit mendapatkan pekerjaan dengan persyaratan yang ketat dan bersifat berkompetitif. Hal ini sangat bertolak belakang dengan keyakinan alumni yang telah bercampur dengan pengalaman mereka dalam mencari pekerjaan, keyakinan mereka untuk mudah mendapatkan pekerjaan sangat rendah selama kuliah di IAIN Lhokseumawe.

Hasil dari kegiatan FGD juga menunjukkan bahwa selama ini lembaga lebih banyak berharap lulusan IAIN Lhokseumawe mendapatkan pekerjaan sesuai dengan program studi masing-masing, tetapi lembaga selama ini tidak berpikir bahwa daya serap pekerja dari lembaga yang membutuhkan sangat sedikit atau tidak seimbang dengan banyaknya lulusan. Hasil wawancara menunjukkan bahwa alumni lebih banyak bekerja di bidang wiraswasta, artinya mereka membuka lapangan kerja sendiri untuk dirinya sendiri. Wiraswasta yang dimaksud disini wira usaha yang dijalankan secara individu. Hasil dari FGD juga mengingatkan lembaga agar tidak hanya memikirkan bagaimana cara untuk memperbanyak mahasiswa, tetapi juga yang terpenting kualitas lulusan yang mampu bersaing untuk mendapatkan pekerjaan atau yang mampu menciptakan lapangan pekerjaan baik untuk diri sendiri maupun orang lain. 
6. Hal-hal yang harus dilakukan lembaga IAIN Lhokseumawe dalam mempersiapkan mahasiswa agar mempunyai kesiapan kerja setelah menjadi sarjana

Kesiapan kerja mahasiswa saat menjadi seorang sarjana sangat di dukung oleh kemauan individu dan peranan lembaga tempat mahasiswa kuliah. Tujuan utama kuliah secara garis besar adalah untuk memudahkan mahasiswa mendapatkan pekerjaan setelah menjadi sarjana. Untuk mendapatkan pekerjaan sekarang ini tidaklah mudah, banyak hal yang harus dilalui oleh seseorang untuk mendapatkan pekerjaan, dari tes tulis, wawancara sampai uji keterampilan. Ini dikarenakan para pencari kerja sudah banyak sekali dan ini sangat menguntungkan bagi lembaga yang membutuhkan pekerja, jelas mereka akan menerima pekerja yang terbaik.

Untuk itu tentu saja mahasiswa harus sedini mungkin mempersiapkan diri agar mempunyai keahlian baik bidang keilmuan maupun keterampilan atau keahlian yang tentu saja harus mengikuti perkembangan zaman. Ini semua harus berawal dari mahasiswa itu sendiri, yaitu mahasiswa harus aktif, keaktifan mahasiswa sangat menentukan pengembangan kemampuan atau kompetensi diri. Oleh karena itu tentu saja pihak perguruan tinggi dalam hal ini IAIN Lhokseumawe harus memikirkan bagaimana cara agar setiap mahasiswa aktif dalam pengembangan kompetensi diri.

Berdasarkan hasil wawancara mahasiswa yang aktif, alumni dan hasil FGD, ada beberapa poin yang terpenting yaitu:

a. Materi perkuliahan disesuaikan dengan perkembangan zaman.

Untuk penguasaan pengetahuan dan teknologi diperlukan adanya pembelajaran dan pelatihan. Tentu ini akan mudah diperoleh pada perguruan tinggi. Perguruan tinggi harus mampu memberikan materi perkuliahan yang setiap berkalanya harus dikaji ulang sesuai dengan perkembangan zaman dan mampu mengikuti teknologi serta memahami bahwa kebutuhan pekerjaan dengan kurikulum haruslah saling melengkapi. Ini bertujuan agar lulusan perguruan tinggi dapat segera dipergunakan oleh penggunanya sesuai dengan kualifikasinya. Selain itu keberadaan teknologi merupakan media atau alat bantu yang akan memfasilitasi kemudahan penyampaian pengetahuan, pesan moral, dan intruksi pembelajaran dari dosen kepada mahasiswa (Permatasari, Sittika, \& Karawang, 2021).

b. Pembentukan wadah untuk pembinaan dan pengembangan bakat dan minat mahasiswa.

Bakat dan minat mahasiswa merupakan salah satu dari kompetensi diri yang perlu dikembangkan. Bakat dan minat mahasiswa biasanya akan berkembang, jika ada pembinaan dan tempat untuk mengaplikasikan bakat dan minat tersebut. Bakat dan minat ini juga dapat dijadikan nilai jual tersendiri bagi lembaga. Artinya bakat dan minat ini dapat dijadikan sebagai promosi lembaga ke publik dengan keikut sertaan dalam ajang perlombaan atau kompetesi antar lembaga perguruan tinggi.

Selain dari itu bakat dan minat merupakan kompetensi yang dimiliki oleh individu, dengan bakat dan minat yang dipunyai oleh mahasiswa membuat mahasiswa sangat optimis untuk kesiapan kerja setelah sarjana. Terkadang bakat dan minat yang dimiliki oleh seseorang sangat dibutuhkan oleh lembaga-lembaga khusus, hal ini dikarenakan tidak banyak orang yang mempunyai bakat dan minat tertentu. Pengembangan bakat dan minat juga mampu membuat seseorang membuka lapangan pekerjaan baik untuk diri sendiri maupun untuk orang lain.

c. Peningkatan keaktifan alumni dalam organisasi

Organisasi alumni lembaga IAIN Lhokseumawe sudah lama terbentuk, kegiatan-kegiatan organisasi ini hanya pada kepengurusan interen, mendiskusikan mengenai akreditasi kampus yang belum maksimal, tetapi kegiatan alumni belum terlihat memberikan hal-hal positif bagi mahasiswa yang aktif. Kegiatan alumni belum mampu menjembatani mahasiswa dan alumni dalam hal informasi-informasi tentang hal-hal yang harus dipersiapkan oleh mahasiswa agar siap untuk kerja dan lowongan-lowongan pekerjaan yang berada di lembaga tempat alumni bekerja berdasarkan pengalaman dari alumni itu sendiri. 


\section{d. Kewirausahan}

Lembaga perguruan tinggi sangat berharap lulusannya bekerja sesuai dengan bidang keilmuannya dan dapat diserap oleh lembaga yang membutuhkan tenaga kerja. Namun demikian tidak semua sarjana akan terserap oleh lembaga yang membutuhkannya. Berdasarkan data BPS (Biro Pusat Statisktik) tahun 2018 menyatakan bahwa $8 \%$ dari 7 juta sarjana adalah menganggur. Kompasiana.com juga menginformasikan bahwa 65\% sarjana bekerja tidak sesuai dengan jurusannya (Nurul, 2018). Pekerjaan yang digeluti oleh sarjana juga masih banyak pekerjaan yang setingkat tamatan SMA, hanya sedikit sarjana yang bekerja sesuai dengan tingkat kesarjanaannya baik pada lembaga pemerintah maupun lembaga swasta. Sulitnya mendapat pekerjaan baik di lembaga pemerintah maupun swasta disebabkan jumlah yang diterima tidak sesuai atau sebanding dengan jumlah sarjana tiap tahunnya.

Pentingnya kewirausahaan untuk mahasiswa dengan sendirinya akan meningkatkan soft skill dan hard skill mahasiswa sekaligus. Jelas soft skill sangat dibutuhkan dalam pengembangan kewirausahaan, karena keahlian komunikasi, mempunyai prilaku yang baik dan tahu membawa diri dalam suatu kelompok merupakan kunci dalam kesuksesan dalam usaha. Sejalan dengan itu hard skill yang merupakan keahlian tersendiri yang dapat dilihat langsung hasilnya juga sangat penting dalam pengembangan kewirausahaan. Hard skill merupakan keahlian utama untuk membangun sebuah usaha, pembuatan produk, penguasaan komputer, manajemen usaha dan lain sebagainya. Jadi soft skill dan hard skill merupakan dua hal yang saling terkait dalam pengembangan kewirausahaan.

Selama ini lembaga perguruan tinggi IAIN Lhokseumawe, pelatihan atau seminar tentang kewirausahaan sangat minim. Malahan fakultas yang non ekonomi tidak pernah ada kegiatan semacam ini. Belum adanya mata kuliah kewirausahaan diterapkan di fakultas selain ekonomi. Oleh karena itu berdasarkan pengalaman alumni baik yang sudah bekerja maupun yang masih menunggu pekerjaan menyatakan bahwa perlu adanya mata kuliah yang mempelajari tentang kewirausahaan yang setiap fakultas ada mata kuliah tersebut atau mata kuliah ini jadikan sebagai matakuliah umum yang biasanya dijadikan sebagai mata kuliah lintas fakultas. Dengan adanya mata kuliah ini diharapkan mahasiswa sejak dini sudah melakukan hal-hal yang kreatif dan inovatif sesuai dengan zamannya dan bermanfaat untuk dirinya dan orang lain.

Hasil penelitian ini diperkuat dengan penelitian sebelumnya tentang pengaruh locus of control terhadap kesiapan kerja siswa SMK (Muyasaroh, Ngadiman, \& Hamidi, 2013), yang menunjukkan bahwa locus of control dapat meningkatkan kesiapan kerja siswa apabila siswa memiliki locus of control yang mampu mengarahkan siswa untuk berperilaku positif dan memiliki tanggung jawab terhadap masa depannya (locus of control internal).

\section{KESIMPULAN}

Berdasarkan hasil hasil pengolahan dan analisis data dapat disimpulkan bahwa tidak terdapat pengaruh yang positif dan signifikan kompetensi diri terhadap kesiapan kerja mahasiswa, ini dikarenakan mahasiswa IAIN Lhokseumawe sangat cenderung menilai kompetensi diri pada nilai indeks prestasi semakin besar pula kesempatan untuk mendapatkan pekerjaan. Mereka tidak menyadari bahwa kompetensi diri itu tidak hanya bidang keilmuan program studi, ilmu yang lain juga harus sedikit banyaknya dikuasai. Tetapi harus mempunyai keahlian ( $(k i l l)$ yang justru banyak dibutuhkan oleh kelompok pengguna pekerja atau keahlian yang dibutuhkan untuk diri sendiri yang nantinya akan dimanfaatkan pada usaha sendiri. Sedangkan pengaruh locus of control mempunyai pengaruh yang positif dan signifikan, dimana mahasiswa yang mempunyai loc internal lebih siap kerja dibandingkan dengan mahasiswa yang memiliki loc eksternal. Temuan dalam penelitian ini berdasarkan hasil wawancara dengan para alumni adalah mereka lebih banyak bekerja pada bidang usaha baik usaha sendiri maupun orang lain yang tidak membutuhkan latar belakang pendidikan yang dimiliki, ini menunjukkan bahwa lembaga perlu memikirkan upaya agar kualitas lulusan mampu bersaing 
3973 Pengaruh Locus Of Control dan Kompetensi Diri terhadap Kesiapan Kerja Mahasiswa IAIN Lhokseumawe - Setiawan, Yusnaini

DOI: https://doi.org/10.31004/edukatif.v3i6.1357

untuk mendapatkan pekerjaan atau mampu menciptakan lapangan pekerjaan baik untuk diri sendiri maupun orang lain yang salah satunya dengan mengasah skill mahasiswa.

\section{DAFTAR PUSTAKA}

Agus Fitriyanto, (2006). Ketidakpastian Memasuki Dunia Kerja Karena Pendidikan. Jakarta: Dineka Cipta,

Bahrul Hayat Dan Suhendra Yusuf, (2010).Mutu Pendidikan, Jakarta: Bumi Aksara

B. Rotter, J. (1996). Genaralized Expectancies For Internal Versus External Control Of Reinforcement. Pshycologycal Monographs, 80, 1-28.

Deny Kumala Jaya Dan Tri Maryati, (2010)Pengaruh Kemampuan, Motivasi Dan Locus Of Control Terhadap Kinerja Individu Melalui Pemediasian Self Efficacy, Jurnal Bisnis Teori Dan Implementasi, No.1 Vol. 2,

Gregory J Feist \& Jest Feist, (2010) Teori Kepribadian: Theories Ofpersonality. Alih Bahasa: Smita Prathita Sjahputri). Jakarta Selatan:Salemba Humanika

Gujarati, D. N. (2003). Basic Ekonometrik. Singapore: Mc Rawhil.

Hamzah B. Uno, Model Pembelajaran, (Jakarta: Bumi Aksara, 2011)

Hana Binti Muyasaroh Dkk, Pengaruh Pengalaman Praktik Kerja Industri Dan Locus Of Control Terhadap Kesiapan Kerja Siswa Kelas Xii Smk Negeri 1 Surakarta (Jurnal Pendidikan Ekonomi, No.1 Vol. 1 Tahun 2013)

Howard S. Friedman, \& Miriam W. Schustack,(2008)Kepribadian: Teori Klasikdan Riset Modern. (Alih Bahasa: Fransiska Dian Ikarini, Maria Hany,Andreas Provita Prima)Jakarta: Erlangga

Husein, U. (2004). Metode Penelitian Skripsi Dan Tesis. Jakarta: Raja Grafindo Persada.

Ivancevich, John M., Konopaske, Robert, \& Matteson, Michael T. (2007). Perilaku Dan Manajemen Organisasi. Edisi Ketujuh. Jilid 1. (Alih Bahasa Oleh Gina Gania). Jakarta: Erlangga, 2007

Mardiani, I., Zulaihati, S., \& Sumiati, A. (2021). Hubungan Antara Locus Of Control Dan Perfeksionisme Dengan Prokrastinasi Akademik Pada Mahasiswa Akuntansi. Edukatif: Jurnal Ilmu Pendidikan, 3(6), 3579-3592.

M. Nur Ghufron \& Rini Risnawita S. (2012) Teori-Teori Psikologi. Yogyakarta: Arruzz Media

Sudjana, (1983) Teknik Analisis Regresi Dan Korelasi Bagi Para Peneliti, Bandung: Tarsito

Suharsimi Arikunto,(2006). Prosedur Penelitian Suatu Pendekatan Praktik, Edisi Revisi Vi,Jakarta : Rineka Cipta

Muyasaroh, H. B., Ngadiman, \& Hamidi, N. (2013). Pengaruh Pengalaman Praktik Kerja Industri Dan Locus Of Control Terhadap Kesiapan Kerja Siswa Kelas Xii Smk Negeri 1 Surakarta. Jupe Uns, 1(1), 1-11.

Nurul, S. (2018). Kompasiana Online.

Permatasari, D., Sittika, A. J., \& Karawang, U. S. (2021). Persepsi Mahasiswa Terhadap Pembelajaran Daring Mata Kuliah Pendidikan Agama Islam Di Masa Pandemi Covid-19. Edukatif: Jurnal Ilmu Pendidikan, 3(6), 3704-3714.

Pool, L. ., \& Sewell, P. (2007). The Key To Employability: Developing A Practical Model Of Graduate Employability. Education And Training Journal, 277-289.

Rahmanto, A. (2010). Hubungan Antara Locus Of Control Internal Dengan Kematangan Karir Siswa Kelas Xii Smkn 4 Purworejo. Jawa Tengah: Thesis Undip.

Seftiawan, D. (2018). 630.000 Orang Sarjana Masih Menganggur. 
3974 Pengaruh Locus Of Control dan Kompetensi Diri terhadap Kesiapan Kerja Mahasiswa IAIN Lhokseumawe - Setiawan, Yusnaini

DOI: https://doi.org/10.31004/edukatif.v3i6.1357

Siswoyo, D. (2007). Ilmu Pendidikan. Yogyakarta: Uny Pers.

Sugiono. (2013). Metode Penelitian Pendidikan. Bandung: Alfabeta.

Sukardi. (2012). Metodologi Penelitian Pendidikan. Jakarta: Bumi Aksara.

Wibowo. (2010). Manajemen Kinerja. Jakarta: Rajawali Pers. 